\title{
TAXES AND THE FINANCIAL STRUCTURE OF GERMAN INWARD FDI
}

\author{
FRED RAMB \\ ALFONS J. WEICHENRIEDER
}

CESIFO WORKING PAPER NO. 1355

CATEgory 1: Public Finance

DECEMBER 2004

\footnotetext{
An electronic version of the paper may be downloaded

- from the SSRN website:

www.SSRN.com

- from the CESifo website:

www.CESifo.de
} 


\title{
TAXES AND THE FINANCIAL STRUCTURE OF GERMAN INWARD FDI
}

\begin{abstract}
The paper analyses the financial structure of German inward FDI. From a tax perspective, intra-company loans granted by the parent should be all the more strongly preferred over equity the lower the tax rate of the parent and the higher the tax rate of the German affiliate. From our study of a panel of more than 8,000 non-financial affiliates in Germany, we find only small effects of the tax rate of the foreign parent. However, our empirical results show that subsidiaries that on average are profitable react more strongly to changes in the German corporate tax rate than this is the case for less profitable firms. This gives support to the frequent concern that high German taxes are partly responsible for the high levels of intracompany loans. Taxation, however, does not fully explain the high levels of intra-company borrowing. Roughly $60 \%$ of the cross-border intra-company loans turn out to be held by firms that are running losses.
\end{abstract}

JEL Code: F23, H25.

Keywords: foreign direct investment, financial structure, taxation, Germany.

\author{
Fred Ramb \\ Deutsche Bundesbank \\ Postfach 100602 \\ 60006 Frankfurt am Main \\ Germany \\ Fred.ramb@bundesbank.de
}

\author{
Alfons J. Weichenrieder \\ Johann Wolfgang Goethe University \\ of Frankfurt \\ Chair of Public Finance \\ 60054 Frankfurt am Main \\ Germany \\ a.weichenrieder@em.uni-frankfurt.de
}

This paper represents the authors' personal opinions and does not necessarily reflect the views of the Deutsche Bundesbank. We thank Ruud de Mooij for valuable advice. Helpful comments from Heinz Hermann, Beatrix Stejskal-Passler, Alexander Lipponer, Frank Stähler and participants of the Kiel Workshop "Multinationals and International Integration" are gratefully acknowledged. Alfons Weichenrieder thanks the German Research Foundation (DFG) for financial support. 


\section{Introduction}

There is widespread concern that multinational firms may evade a large portion of their statutory tax burden by shifting income out of high-tax jurisdictions. While such a concern is certainly not restricted to Germany, the high statutory rates of corporate tax in Germany - at least until the recent tax reform in 2001 - make it most likely that the country is particularly prone to this problem. Throughout the 1990s Germany had the highest tax rate on retained corporate profits (including average local taxes) among OECD countries.

Income shifting may take the form of prices that depart from arms-length conditions and may imply excessive management and overhead fees, the setting of nonmarket interest rates within a group etc. Besides setting tax-efficient transfer prices on intra-firm trade, multinationals may also use the financial structure to minimise taxes and thereby allocate interest deductions to highly taxed affiliates for which this tax shield is most valuable. In this paper we want to explore to what extent the financial structure of German inward foreign direct investment (FDI) is due to tax-saving behaviour. ${ }^{1}$ During the 1990 s the net German FDI inflow was financed to a large extent by intra-company debt incurred outside Germany. According to Deutsche Bundesbank (1993), 61.9\% of the German inflow of FDI in 1990 and 1991 was financed by intracompany loans, and this strong role of intra-company loans in German inward FDI has led to the suspicion that these loans are indeed encouraged by high German tax rates (Deutsche Bundesbank 1997, page 67f, Weichenrieder 1995, page 183). To the best of our knowledge this paper is the first attempt to look at this question using German firmlevel data on inward FDI.

Our study is based on the Bundesbank FDI statistics that cover all foreign direct investments, which meet mild size requirements. Unlike most studies on FDI with non-

\footnotetext{
1 For papers that provide evidence on tax motivated transfer pricing policies of multinationals see, for example, Grubert and Mutti (1991), Collins and Shackelford (1998), or Rousslang (1997).
} 
U.S. data, we can draw on micro data from 1989 - 2002 to study this question and a panel structure is available for the years $1996-2002 .^{2}$

While there is a large number of studies on the tax effects on FDI, most are concerned with the effect of local taxes on the overall FDI inflow of a region. ${ }^{3}$ There are only a few studies on the financial structure. Notable exceptions are studies by Altshuler and Grubert (2003), Jog and Tang (2001), and Desai, Foley, and Hines (2003a). Altshuler and Grubert consider a cross sample of US subsidiaries abroad and analyse the liability and asset side of these firms. The study shows an inverse relationship between the foreign tax rate and the amount of financial assets held abroad. On the liability side, a 1 percentage point increase in the foreign tax rate is associated with an increase of roughly .4 percentage point in the debt to total asset ratio. The paper by Jog und Tang looks at US and Canadian firms. The authors show that the reduction in the Canadian corporate tax rate in the late 1980s triggered a reduction in the debt ratio of Canadian affiliates. Finally, Desai, Foley, and Hines find for a panel of US-owned foreign firms that a 1 percentage point increase in the foreign corporate tax rate leads to an increase in the external debt to asset ratio of roughly .25 percentage point and an increase in internal borrowing of some .08 percentage point.

In section 2 we will briefly discuss the tax arbitrage possibilities of multinational firms that consider alternative ways of financing their German investment. In Section 3 the Deutsche Bundesbank FDI database is used to present descriptive statistics of financial structures of German inward FDI. ${ }^{4}$ By identifying the home countries of foreign affiliates operating in Germany and employing the respective tax rate of the parent, we are able to proxy the global tax saving of a profitable firm that decides to distribute a euro of equity to its parent and to replace this euro by an intra-company loan granted by the parent. Section 4 develops the empirical model and presents the econometric results before section 5 concludes.

Our empirical analysis of a huge panel of more than 8,000 firms provides evidence that supports the hypothesis that the financial structures of foreign affiliates in Germany are partly tax motivated. While we find that the corporate tax rate of the

\footnotetext{
2 For reasons of data protection the data before 1996 have been anonymised, and the panel structure has therefore been lost.

${ }^{3}$ For a detailed survey and meta study see Ederveen and de Mooij (2001).
} 
parent has only a very limited impact on the financial structure of a German subsidiary, a significant effect of the German tax rate is visible. To identify this influence, we exploit the fact that unprofitable firms should be less affected by a change in the German corporate tax than profitable firms. Indeed, our results show that among German subsidiaries, which are directly held by a foreign investor, profitable firms react significantly different from non-profitable firms. When the German tax rate increases, profitable firms significantly increase the amount of intra-company debt compared to unprofitable firms.

Besides tax incentives, our study identifies (low) profitability as a major factor that explains the diversity of intra-company loans. Roughly $60 \%$ of the cross-border intra-company debt turns out to be held by firms that are running losses and profitability turns out to be highly significant in our panel regressions of intra-company loans.

\section{The tax preferences for intra-company loans}

From a tax perspective, the incentives for a foreign parent to grant an interest bearing loan to a profitable German subsidiary will depend on the German tax rate at which the interest is deductible, on the one hand, and the tax rate at which the interest is taxable in the home country of the parent, on the other hand.

To be more specific, consider the option of a German affiliate to use its profit to pay back an intra-company loan granted by the parent. Let $\tau_{r}{ }^{*}, \tau_{d}{ }^{*}, \tau_{i}{ }^{*}$ be the effective corporate tax rates on German retained earnings and on earnings that are distributed from the German subsidiary to the foreign parent and the rate at which the German affiliate can deduct interest paid to the parent. The latter rate may fall short of the rate on retained earnings since in Germany only half of the interest on medium and longterm debt is deductible from the local trade tax (Gewerbesteuer). The rate $\tau_{d}{ }^{*}$ is an effective rate that is influenced by the German corporate tax on distributed profits, by the German withholding tax on dividends and by additional taxes in the home country of the parent if this country does not exempt foreign dividends.

\footnotetext{
${ }^{4}$ For a description of this database see Lipponer (2003).
} 
If the German affiliate pays back a loan of $€ 1$ today, the parent is able to distribute this $€ 1$ as a dividend to its own shareholders. This however, comes at a cost. To pay back a loan of $€ 1$, the German affiliate needs a pre-tax income of $1 /\left(1-\tau_{r}{ }^{*}\right)$ euro. Since this sum is not available for profit distribution, the parent forgoes $\left(1-\tau_{d}{ }^{*}\right) /\left(1-\tau_{r}{ }^{*}\right)$ euro in dividends. Hence, the total change in dividends that the parent can pay today (before personal taxes of the shareholder of the parent) is given as

$$
a \equiv 1-\frac{\left(1-\tau_{d}{ }^{*}\right)}{\left(1-\tau_{r}{ }^{*}\right)}
$$

There is, however, an additional effect on future dividends. Since the debt service of the affiliate drops by the tax deductible interest rate on the retired loan, dividends may rise by $i\left(1-\tau_{i}{ }^{*}\right)$ in all future periods, where $i$ is the nominal interest rate. Since these dividends are taxed at the rate for distributed profits rather than at the rate on retained earnings, the parent receives a stream of dividends of $i\left(1-\tau_{i}^{*}\right) \cdot\left(1-\tau_{d}^{*}\right) /\left(1-\tau_{r}^{*}\right)$, the cash value of which is

$$
b \equiv \frac{i\left(1-\tau_{i}{ }^{*}\right) \cdot\left(1-\tau_{d}{ }^{*}\right)}{\left(1-\tau_{r}{ }^{*}\right) \cdot i(1-m)},
$$

where $i(1-m)$ is the discount rate applied by a shareholder of the parent.

A third effect that has to be taken into account is that the parent in all future periods lacks the interest income on the retired euro. Denoting the parent firm's tax rate at which the interest is taxable by $\tau$, the cash value of this effect amounts to

$$
c \equiv \frac{i(1-\tau)}{i(1-m)}
$$

Obviously, assuming constant tax rates and abstracting from taxes on capital gains, the profitability of the intra-company loan depends on the sign of $(a+b-c)$. If this sign is negative, intra-company loans dominate equity in the form of retained earnings as a source of finance for the German affiliate. One problem in international studies such as ours is that one can only speculate about the applicable tax rate $m$ of the 
final investor. We follow a standard assumption in the literature on the international cost of capital (OECD 1991) and assume that the final investor is tax exempt $(m=0)$. Consequently,

$$
D I F F=-(a+b-c)=\left(1-\tau_{d}{ }^{*}\right) \tau_{i}{ }_{i}^{*} /\left(1-\tau_{r}{ }^{*}\right)-\tau
$$

is an indicator of the tax dominance of intra-company loans over retained earnings of the German affiliate. It should be noted that DIFF is also the relevant indicator for the tax advantage of reducing the third-party debt of the German affiliate by $€ 1$ and increasing the third-party debt of the foreign parent by $€ 1$. In this case the capital market can be thought of as financing a back-to-back transaction with the affiliate and the parent. Moreoover, things are very similar if the corporation is considering a new equity injection by the parent or, alternatively, an intra-company loan to finance the subsidiary. Again, it can be shown that the relationship between the German and the foreign tax rates is crucial. ${ }^{5}$

The above arbitrage argument assumed that the parent and the German affiliate are profitable and do pay taxes. For German firms that are unprofitable, however, the right to deduct interest from the high taxed German tax base tends to be less valuable. At best, such a firm may be able to use a loss carry-backward or a loss carry-forward to decrease taxable income in other fiscal years. In the case of a loss carry-forward this comes at a cost as the loss carry forward is not interest bearing. The effective rate at which interest is deductible reduces. Conversely, if the parent firm, which receives the interest income, is running losses, then the effective tax rate may be lower than the statutory tax rate $\tau$. Unfortunately, we do not know about the tax status of the parent so we cannot exploit such a difference in effective rates.

From the above argument we have that the profit or loss position of the German affiliate changes the influence of the Germany tax rate since it may reduce the value of the interest deduction, but, given the profit or loss position of the parent, it does not change the effective tax rate at which interest income of the parent is taxed. This suggests to split up the variable DIFF into a German part and a foreign part when the

\footnotetext{
${ }^{5}$ For an extensive discussion of the tax-induced financial preferences of multinational firms see Alworth (1988), Keen (1991) or Weichenrieder (1995).
} 
profit or loss position of the German subsidiaries is considered in the empirical implementation. Firms that do pay taxes are expected to react more strongly to a German tax rate change than firms that are in a loss position.

\section{Descriptive statistics}

Despite its recently sluggish growth rates, Germany is still one of the main recipients of inward FDI. For end-2000 the OECD FDI statistics record an inward stock of FDI of $€ 482$ billion for Germany compared €277 billion for France, €121 billion for Italy and $€ 479$ billion for the UK. The present section gives information on the overall financing patterns of the German FDI stock and additional stylised facts. We will concentrate on non-financial firms (excluding banks, pure holding companies, and insurance companies) that are separately incorporated in Germany (dropping branches), and we will exclude investment in the government and not-for-profit sectors.

In its yearly survey of the stock of German inbound FDI, the Bundesbank collects data on the liability side of the balance sheets such as paid-up capital, capital reserves, profits and losses carried forward, and debt, including loans received from affiliated firms inside and outside Germany. The prime purpose of the data collection is to give a picture of the cross-border ownership of firms and the stocks of FDI in Germany. A somewhat unusual feature of the balance sheets collected by the Bundesbank is that they contain the yearly profit after taxes but before dividend distributions as a separate part of the equity of the firm. Therefore the balance sheets provide information on current profits despite the fact that there is no explicit profit and loss statement. On the asset side, data are available on fixed assets and intangibles, financial assets and working capital.

For each firm in the sample we can identify the foreign country of the investor, which may not be the ultimate investor but a foreign holding or intermediate company, and the share that this investor has in the German affiliate. An important distinction in the German data is the one between directly and indirectly held inward FDI. An indirect participation applies if the German affiliate is held by a German company that, in turn, is owned by a foreign investor. A direct participation is defined as one where the German affiliate is directly owned by a foreign investor. 


\section{Figure 1. Main investors by country}

a) Directly held affiliates

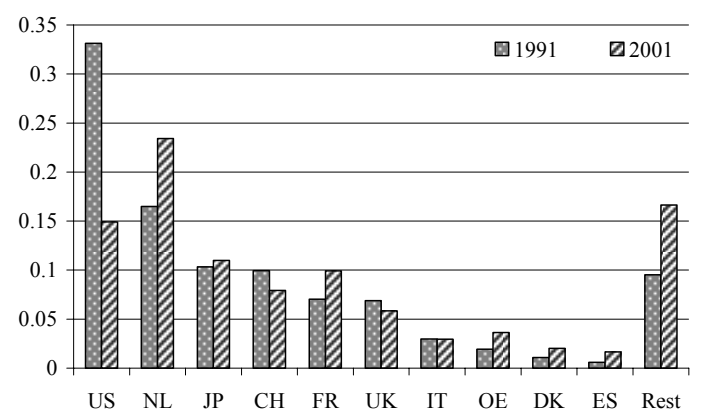

b) Indirectly held affiliates

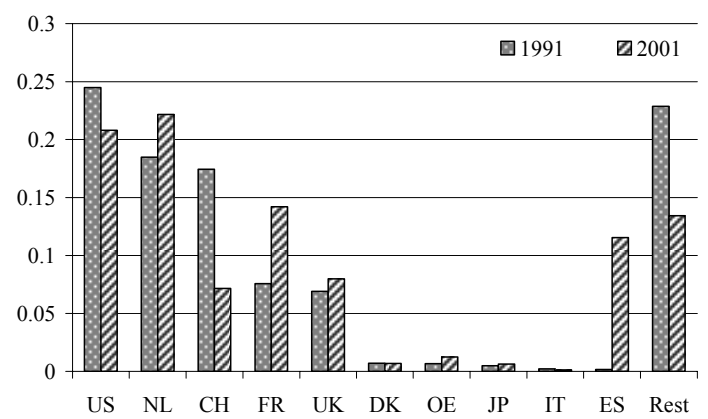

Annotation: Investor countries by relative contribution to balance sheet total of directly and indirectly held foreign affiliates in Germany. United States (US), Netherlands (NL), Japan (JP), Switzerland (CH), France (FR), United Kingdom (UK), Italy (IT), Austria (OE), Denmark (DK), Spain (ES). Source: Deutsche Bundesbank database. Subsample of non-financial firms.

As has been found for US data, most of the FDI is wholly-owned. In 2002, for example, almost $70 \%$ of the directly held subsidiaries had only one foreign investor. Figure 1 shows how the total assets of the affiliates can be attributed to investors from different countries. Allthough the investors of German inbound FDI are rather unevenly spread out across investing countries, there remains a rather large number of investments coming from smaller countries. Figure 1 shows a dominance of US investors, which has seemingly declined during the 1990s. This may be partly due, however, to the increased use of (often Dutch) intermediate holdings (cf. also Desai, Foley and Hines 2003b, Mintz 2003). 
Table 1. Descriptive statistics, aggregated sample (2001)

\begin{tabular}{lcccc}
\hline \multirow{2}{*}{ Balance sheet item } & \multicolumn{2}{c}{ Direct } & \multicolumn{2}{c}{ Indirect } \\
& $\begin{array}{c}\text { Total } \\
(€ \text { billion })\end{array}$ & $\begin{array}{c}\text { Fraction of } \\
\text { balance sheet }\end{array}$ & $\begin{array}{c}\text { Total } \\
(€ \text { billion })\end{array}$ & $\begin{array}{c}\text { Fraction of } \\
\text { balance sheet }\end{array}$ \\
\hline Paid-up capital & 19.200 & 10.6945 & 20.600 & 8.7026 \\
Capital reserves & 39.400 & 21.9686 & 28.400 & 11.9889 \\
Surplus reserves & 2.151 & 1.1991 & 6.498 & 2.7394 \\
Profit/loss carry-forward & -10.900 & -6.0962 & -2.459 & -1.0367 \\
Current profits & -1.515 & -0.8447 & 1.424 & 0.6003 \\
Debt & 94.300 & 52.5342 & 126.000 & 53.1273 \\
$\quad$ Liabilities to affiliated & 47.200 & 26.3162 & 75.900 & 32.0105 \\
$\quad$ companies & & & & \\
$\quad$ in Germany & 11.300 & 6.3081 & 58.800 & 24.8007 \\
$\quad$ outside Germany & 35.000 & 19.5071 & 15.400 & 6.4763 \\
Other liabilities & 36.900 & 20.5447 & 56.600 & 23.8784 \\
Balance sheet total & 179.000 & 1 & 237.000 & 1 \\
\hline \hline
\end{tabular}

Let us now turn to the financial structure. Table 1 gives the crude picture. In 2001 the balance sheet total of directly held firms amounted to $€ 179$ billion. ${ }^{6}$ About $11 \%$ of this was financed by paid-up capital and some $23 \%$ consisted of retained earnings from previous periods (capital and surplus reserves). On aggregate, loss carry-forwards amounted to roughly $6 \%$. Debt and other liabilities made up for roughly $73 \%$ of the aggregated balance sheets. The financing pattern changes when we turn to indirectly held firms, i.e. corporations that are not directly held by a foreign company but held via an intermediate company located within Germany. The two types of firms differ with respect to the capital reserves, the loss carry-forwards and the liabilities to affiliated companies. While overall debt makes up for roughly $53 \%$ of the balance sheets in both cases, indirectly held firms tend to owe more to affiliated companies. Moreover, the structure of these liabilities differs between the two types of firms. Indirectly held firms tend to owe most of this (25\% of the balance sheet) to affiliate companies within Germany and directly held firms owe most of it (20\%) to affiliated firms outside Germany. This reflects the fact that indirectly held firms are owned by German intermediate companies that can act as financial clearing institutions for their 
subsidiaries. Conversely, directly held subsidiaries are held by a foreign firm or foreign holding company and are less likely to face an affiliated company in Germany. By international standards, the amount of cross-country intra-company debt looks large. For comparison, Desai, Foley, and Hines (2003a) report that US-owned foreign affiliates, on a worldwide average, finance $8 \%$ of their total assets by borrowing from their US parent. Similarly, Altshuler and Grubert (2003) report for a sample of 5,981 US-owned non-financial subsidiaries that loans from stockholders amounted to roughly $10 \%$ of total assets in 1996. German non-financial FDI abroad is also financed by intracompany loans to a much lesser extent. In 2001 the liabilities of those firms to German affiliates (including their German parent) amounted to some $8.7 \%$ of the balance sheet total and the liabilities to non-German affiliates were $8.3 \%$.

The summary statistics of Table 1 do not, of course, reflect the possibly large heterogeneity in the data across firms and across investor countries. Therefore, Figure 2 gives some information on firm heterogeneity. Each of the 12 graphs ( 6 for direct and 6 for indirect participations) contains 5 lines. The bold line represents the respective financing ratio of the median firm, i.e. $50 \%$ of the firms have a lower financing ratio. The other curves represent the financing ratios for the $5 \%, 25 \%, 75 \%$ and $95 \%$ centile firms.

Several features are remarkable. As shown in the first graph of Figure 2, after the year 1996 more than $5 \%$ of the firms had paid-up capital that amounted to more than $100 \%$ of total assets. Technically, this is possible if there are negative items on the liability side of the balance sheet such as loss carry-forwards or current losses.

\footnotetext{
${ }^{6}$ Due to an increase in the thresholds for the reporting requirement, the year 2001 is somewhat more representative for our data than the year 2002.
} 


\section{Figure 2. Diversity in financial ratios}
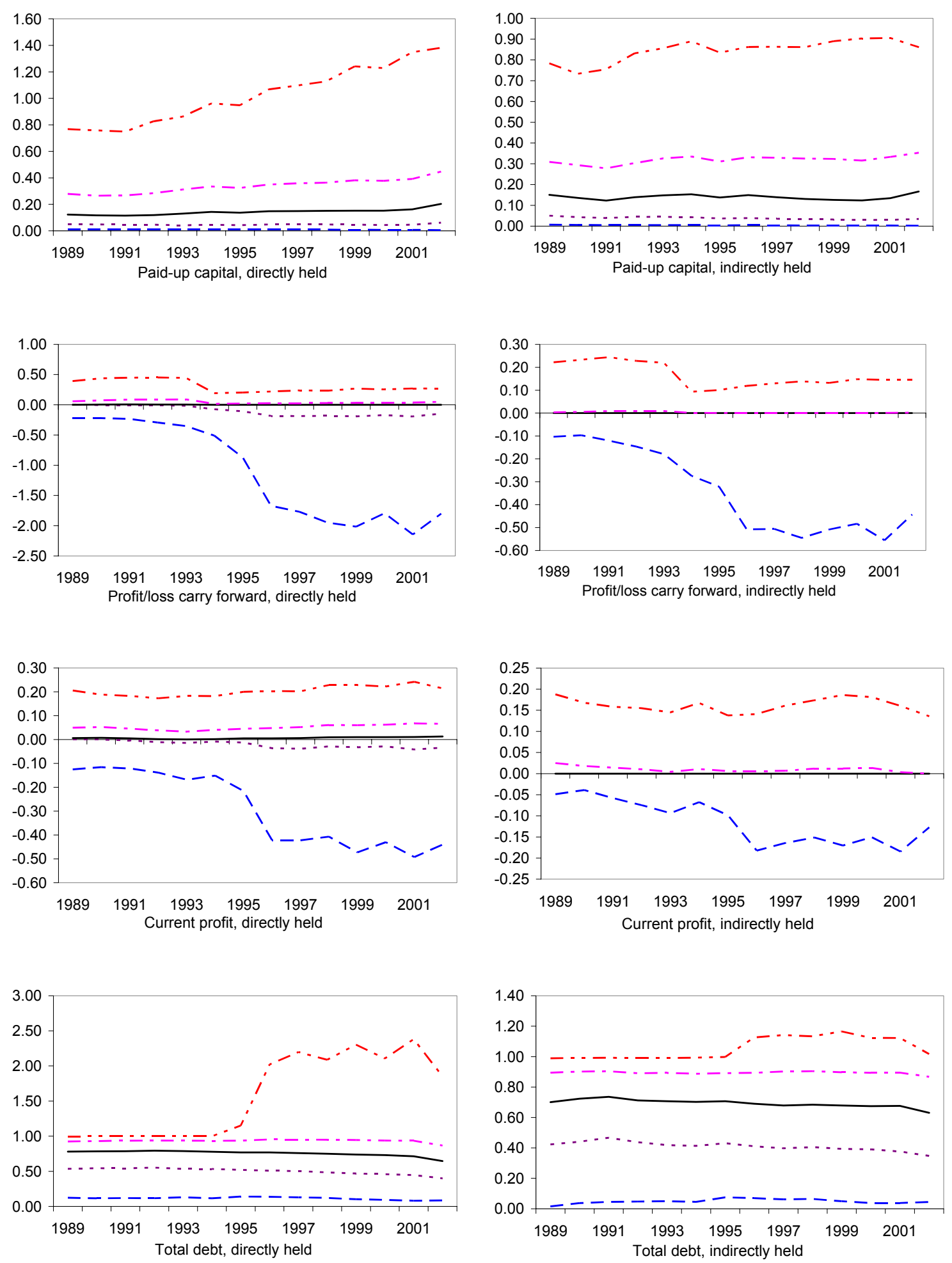


\section{Figure 2 cont'd}
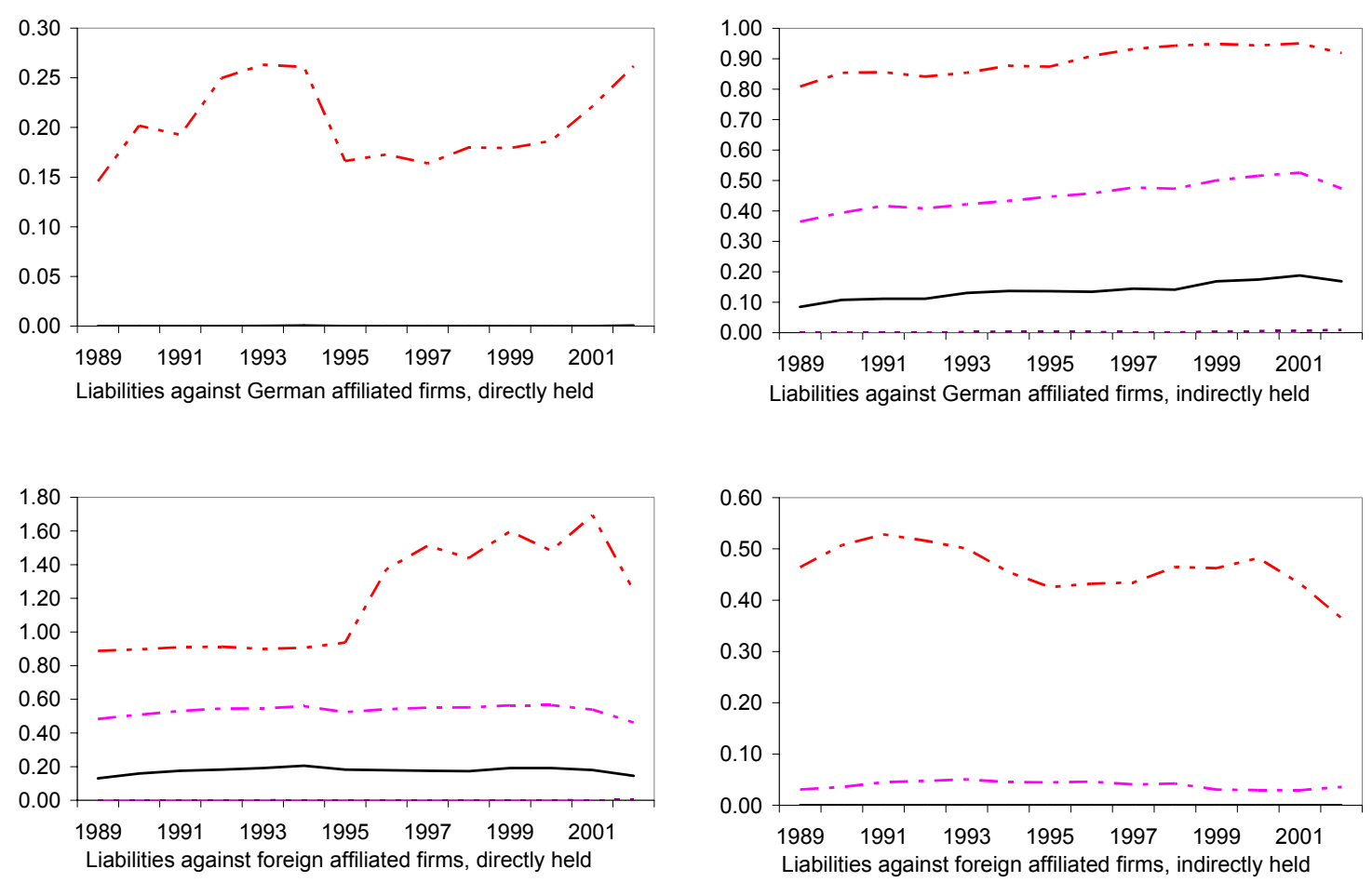

Annotation: In each graph, the bold line indicates the respective financial ratio of the median firm. The two lines below the median line characterise the financial ratio of the 5 th and 25 th centile firms, the two lines above the median ratio indicate the 75th and 95th centiles. Each of the left hand diagrams refers to the subsample of firms that are directly held by a foreign firm, while the graphs on the right hand refer to firms in Germany that are foreign held via a German company.

Indeed, from 1993 onwards, directly held affiliates experienced growing loss carry-forwards. The value of a firm that represents the fifth centile in terms of this balance sheet item has doubled from 1995 to 2002 and amounted to $180 \%$ of the balance sheet total at the end of the period, implying negative equity. For $5 \%$ of the indirectly held firms loss carry-forwards still exceeded $44 \%$ of the balance sheet. From 1993, extreme outliers are present also when we consider current net-of-tax profits of directly and indirectly held firms. In 1995, 5\% of the directly held affiliates had a current loss that exceeded $21 \%$ of their balance sheet and, by the year $2002,5 \%$ of the firms had a yearly loss that amounted to at least $44 \%$ of their balance sheet total. In the case of indirectly held affiliates, losses for the fifth centile reached $10 \%$ of the balance sheet total in 1995 and $13 \%$ in 2001 . It should be noted that a growing number of firms are running huge losses in consecutive years. While the huge number of unprofitable 
operations is surprising, it is also remarkable that a large number of firms report exactly zero net-of-tax profits and this holds true for the median directly and indirectly held firms in almost any year from 1989 to 2001 .

Turning to total debt, in recent years $5 \%$ of the directly held affiliates have had a share of debt in balance sheet total that exceeded unity. As with paid-up capital, this is possible in the case of negative current profits and/or negative profit carry-forwards. Finally, for at least $5 \%$ of the directly held subsidiaries liabilities to affiliated firms outside Germany account for more than $100 \%$ of the balance sheet total after 1995 . For the fifth centile, the fraction is growing and was 1.24 in 2002. Interestingly, the development of the internal debt in this centile closely corresponds to the development of losses for the fifth centile. Quite obviously, for some firms current losses are covered by intra-company loans instead of new equity.

To sum up the above description, in the second half of the 1990s the financial structure of a sizeable fraction of the inward FDI projects in Germany was strongly influenced by large losses and this holds particularly for directly held firms. In many cases losses were accumulating over time and to some extent intra-company loans were used to finance these losses. While corporate losses seem to play a huge role in explaining the financial structures of some firms, the next sections will analyse what role is left for tax differences between Germany and the home country of the investor. Before we will do so, however, we will briefly introduce our tax rate data.

Figure 3 gives an impression of the distribution of DIFF, as defined in section 2, for the full sample of all directly and indirectly held affiliates in our data set with all years pooled. ${ }^{7}$ The data set contains tax information from up to 69 countries and digests information on the foreign corporate taxes including average local taxes, the German withholding tax on dividends and the German corporate tax (including average local taxes) against which firms can deduct interest expenses. ${ }^{8}$ In cases, in which a German firm is owned by several investors from foreign countries, we use average values of

\footnotetext{
${ }^{7}$ In those cases where the affiliate is owned by foreign investors from more than one country we calculate DIFF as a weighted average of the individual country values (weights taken from the ownership of shares).

${ }^{8}$ In selected cases, we decided to depart from headline corporate taxes in investor countries due to special regimes. For example, a huge fraction of German subsidiaries is held via Dutch holdings. Since 1997, these holding can allocate 80 per cent of their interest income to special provisions, which in effect exempts 80 per cent of the income. Therefore we adjusted the Dutch tax rate accordingly.
} 
DIFF, with the fractions of the ownership stakes taken as weights. Rather than showing the histogram itself, Figure 3 gives a Kernel density estimate, which makes it somewhat easier to compare the distribution with a normal distribution. For a very large share of the observations DIFF is positive implying that for tax reasons it pays for a profitable multinational to substitute intra-company debt for equity (i.e. to distribute retained earnings). But owing to the German split rate system of the corporate tax with its smaller rate on distributed profits and the limited tax deductibility of interest against the local taxes for some countries during the 1990s, DIFF was (partly) negative. Italy and Japan are examples. When we look at the time variation in the tax rate data, 62 per cent of the home countries in our sample did experience corporate tax rate changes during the period 1996-2002 and the average standard deviation of the national corporate tax rate is some two percentage points.

\section{Figure 3. The distribution of DIFF}

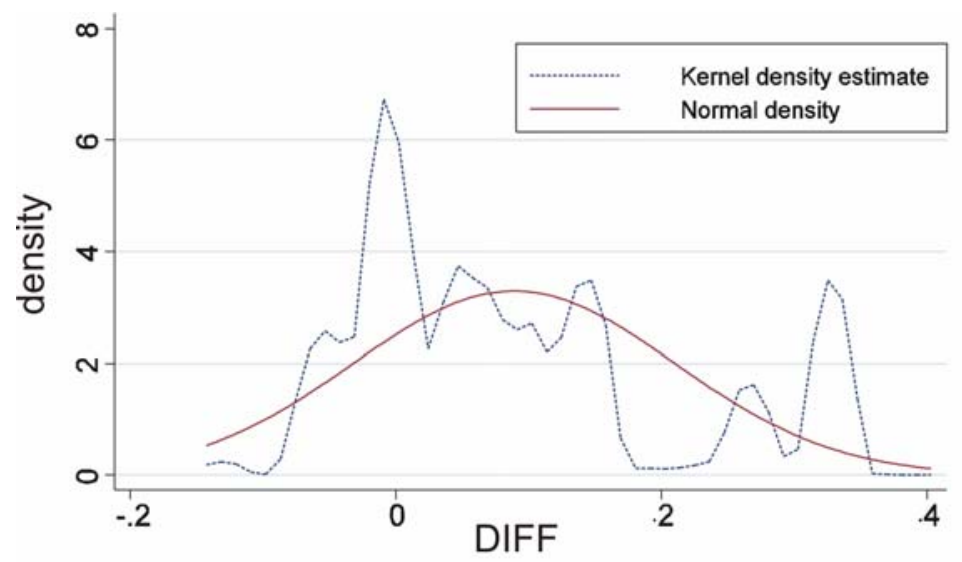




\section{$4 \quad$ Empirical Evidence}

The role of taxes on the financial structure has been widely analysed in empirical studies, but most studies are concerned with national firms and national tax systems. ${ }^{9}$ While the older literature has generally failed to find significant effects on corporate financing, recent studies of national firms have been more successful in identifying tax effects. MacKie-Mason (1990) looks at the marginal source of finance as a function of the corporate tax rate by looking at the loss carry-forward position of firms. For firms with high loss carry-forwards the tax deductibility of interest has a lower value than for profitable firms. MacKie-Mason shows for a sample of US corporations that firms with high loss carry-forwards indeed use less debt at the margin. Givoly et al (1992) use a similar method and use the natural experiment of the US 1986 tax reform act. Gentry (1994) compares US firms that operate in special industries and can avoid the double taxation under the US corporate tax system with other firms that are subject to double taxation of corporate profits. Indeed the first group of corporations shows a significantly different financing behaviour. Graham (1999) argues that empirically the tax rate of the personal investor plays a role in corporate financing decisions. Gordon and Lee (1999) exploit the fact that in the US smaller corporations are granted a lower corporate tax rate and find a significant effect of this lower rate. Finally, Gropp (2002) shows a sizeable tax effect on the financing of marginal corporate investment by exploiting local tax differentials for German firms.

So far, there is rather limited evidence on the empirical effects of international taxation on the financing of multinationals. Three notable exceptions have been described in the introduction, and all of them identify effects for US-owned subsidiaries.

In this study we want to address the question of how tax rate differences between the home country of an investor and Germany influence the financial structure of German inward FDI. Therefore, the endogenous variable that is of foremost interest to us is the amount of intra-company loans granted to a German affiliate by its foreign investor divided by the balance sheet total (LIABOUTGER). As we cannot exactly distinguish from which country a loan is granted we employ the working hypothesis that

\footnotetext{
${ }^{9}$ There is a huge theoretical literature on the determinants of the financial structure of corporations. A useful survey of this literature is given in Harris and Raviv (1991).
} 
all debt from non-German affiliated companies comes from the parent and the applicable tax rates for this country are taken into account.

Table 2. Determinants of cross-border intra-company loans

\begin{tabular}{ccccc}
\hline \hline & $\begin{array}{c}(1) \\
\text { Directly held } \\
\text { affiliates }\end{array}$ & $\begin{array}{c}(2) \\
\text { Indirectly held } \\
\text { affiliates }\end{array}$ & $\begin{array}{c}(3) \\
\text { Directly held } \\
\text { affiliates }\end{array}$ & $\begin{array}{c}(4) \\
\text { Indirectly held } \\
\text { affiliates }\end{array}$ \\
\hline DIFF & -0.024 & 0.021 & & \\
CT & $(0.016)$ & $(0.008)^{* * *}$ & & -0.007 \\
GERTAX & & & 0.003 & $(0.011)$ \\
& & & $0.014)$ & -0.014 \\
PROFITABILITY & -0.302 & -0.073 & $(0.054)^{* *}$ & $(0.007)^{* *}$ \\
& $(0.033)^{* * *}$ & $(0.025)^{* * *}$ & -0.293 & -0.062 \\
SIZE & 0.053 & 0.001 & $0.03)^{* * *}$ & $(0.027)^{* *}$ \\
COLLATERAL & $(0.006)^{* * *}$ & $(0.001)$ & $(0.006)^{* * *}$ & $(0.001)$ \\
& -0.066 & -0.066 & -0.064 & -0.065 \\
Observations & $(0.018)^{* * *}$ & $(0.012)^{* * *}$ & $(0.018)^{* * *}$ & $(0.012)^{* * *}$ \\
Number of firms & 25,540 & 15,090 & 25,821 & 15,318 \\
R-squared & 4,985 & 3,314 & 4,985 & 3,314 \\
\hline \hline
\end{tabular}

Notes: Dependent variable: liabilities to affiliated companies outside Germany over the balance sheet total. Standard errors in parentheses; * significant at 10\%; ** significant at 5\%; *** significant at $1 \%$. Unbalanced sample for the years from 1996 to 2001. Firm fixed-effects (within) estimator. Standard errors are corrected for clustering across country observations and for heteroscedasticity. A full set of time dummies has been used; coefficient estimates are not reported. We eliminated outliers by excluding observations for which the exogenous variables PROFITABILITY, COLLATERAL and SIZE were either in their two lowest or in their two highest percentiles. We also excluded firms that on average across all observations had a debt to asset ratio of unity or larger. To be included observations had to be consecutive for at least three years. Total assets are used on both sides of the equation in the denominators of LIABOUTGER, COLLATERAL and PROFITABILITY. Since this poses potential endogeneity problems, we also used instrumental variables approaches (using a GMM model) but the test statistics always rejected the validity of the available instruments. Therefore the GMM results are not reported.

Table 2 summarises our findings for the liabilities to non-German affiliated companies (cross-border intra-company loans). Since the Breusch-Pagan and the Hausman tests reject the use of random-effects models, we report only the results for fixed-effects models. Because of the quite different importance of cross-border intracompany loans for directly and indirectly held affiliates we analyse them in separate subsamples. Columns (1) and (2) report the results for a model in which the variable DIFF summarizes the tax incentives to borrow from the parent. From section 2, we should expect that DIFF is positively correlated with the amount in intra-company loans. The model behind columns (3) and (4) splits up the effects of the foreign tax rate and the German tax rate. A larger foreign tax rate should lead to heavier taxation of 
interest paid by the affiliate and should make cross-border loans less attractive. We therefore expect a negative coefficient. Conversely, the higher the German rate, the higher is the value of interest deductions and the more cross-border loans should be expected. The problem here is that the German statutory tax rate is the same for all firms in our sample. In a model with fixed time effects the respective coefficient therefore cannot be identified. To overcome this problem we split our sample into a subsample of firms that on average show a positive profitability and into a second subsample of firms that have zero or negative average profitability across observations. A dummy PROFIT takes on the value one for a firm in the first subsample and the value zero, otherwise. ${ }^{10}$ The variable GERTAX is the product of this dummy and the German corporate tax rate as it is relevant for interest deductions. As has been argued in section 2, profitable (i.e. taxable) firms can be expected to react more strongly with their leverage decision upon a German tax rate change. Therefore we expect a positive coefficient of the variable GERTAX, which also has a sizeable variation over the years since the German tax rate relevant for interest deductions has come down from $59.65 \%$ in 1996 to $33.07 \%$ in 2002 .

Columns (1) and (2) use the variable DIFF, columns (3) and (4) use CT and GERTAX. The tax variable DIFF is found to be non-significant for directly held firms in column (1). This result changes if we look at indirectly held firms in column (2). Here the coefficient is significant, but is still economically small. It suggests a .2 percentage point increase in the ratio of cross-border loans to total assets if the home country rate increases by 10 percentage points.

A possible reason for this weak correlation is that a large percentage of the firms in our sample have negative profits in consecutive years. The models in columns (3) and (4) report the results for variables CT and GERTAX and try to overcome this problem. We find that the influence of the parent's home tax rate, CT, is still insignificant for directly and indirectly held affiliates. Turning to the coefficient GERTAX we find a significant and sizeable effect for directly held firms that receive the major part of crossborder intra-company loans. The coefficient implies that an increase of the German tax rate of 10 percentage points increases the fraction of cross-border loans to balance sheet

\footnotetext{
${ }^{10}$ For 68 per cent (42 per cent) of the directly (indirectly) held firms in the sample of Table 2, PROFIT takes on the value one.
} 
total by some 1.37 percentages points relative to the control group that on average shows non-positive profitability. Surprisingly, we get a negative sign of GERTAX when analyzing the indirectly held affiliates in column (4), which from the descriptive statistics in section 3 receive much less cross-border loans. While it is statistically significant, the coefficient for these firms is very small in economic terms.

Drawing on the empirical model of Rajan and Zingales (1995), we add several other variables that may play a role for the financial structure. A large ratio of fixed assets to total assets can be interpreted as a sign for good collateral. This may reduce the agency cost of borrowing and may increase firm value in the event of illiquidity of the firm. This in turn should increase the availability of third-party debt and may reduce the need for loans by the parent. This leads us to introduce the ratio of fixed assets and intangibles to total assets as the explanatory variable COLLATERAL. ${ }^{11}$ COLLATERAL has a significantly negative coefficient for all but one subsample (profitable indirectly owned affiliates). This is in line with a substitution theory between intra-company debt and third-party debt and the hypothesis that collateral increases the access to third-party debt.

Access to third-party debt may also vary with firm size. If larger corporations are more diversified than smaller ones, the former may have a smaller default risk and better access to outside debt (reducing the need for intra-company debt). But, of course, larger corporations may simply be better equipped with equity and may need less thirdparty debt as well as less intra-company loans. In any case, size may matter, and we therefore introduce the right-hand variable SIZE, defined as the log of total assets (balance sheet total). The coefficient for size turns out to be insignificant for the sample of indirectly held firms but significantly positive for the directly held affiliates, which may reflect that large, mature firms have a better equity base.

While the significance of the variable GERTAX is evidence that tax considerations do matter for the size of cross-border intra-company loans, this may not be the full story. Indeed, only some $55 \%$ of the German affiliates are financed by crossborder intra-company loans. As we have seen from the descriptive statistics, a sizeable fraction of the foreign subsidiaries in Germany run huge losses and intra-company loans 
seemed to be an important instrument to keep those firms alive. In total, $60 \%$ of all cross-border intra-company loans are granted to affiliates that are in a loss position and therefore have a limited benefit from interest deductibility. This alone suggests a strong role of cross-border loans in covering losses. Another piece of evidence for the role of losses is the coefficient of the variable PROFITABILITY in Table 2, which is defined as the ratio of current profits net of taxes to total assets. We find a significant negative and sizeable correlation between PROFITABILITY and cross-border intra-company loans for directly held firms. The marginal effects reported in Table 2 indicate that a reduction in profits of $1 \%$ of the balance sheet total leads to additional cross-border loans of $.3 \%$ of the balance sheet total. While PROFITABILITY is also significant in explaining the intra-company loans for indirectly held firms, the estimated coefficients are much smaller. This reflects the fact that for indirectly held firms a German intermediate company is available to provide short-term finance and cross-border loans are largely redundant.

As mentioned in section 2, a close substitute to an intra-company loan is to increase third party debt of the high-tax affiliate in Germany and to reduce third party debt of the parent firm. ${ }^{12}$ For parent firms in low-tax jurisdictions (high DIFF) debt is less advantageous from a tax saving perspective and parents may use less leverage. This in turn allows them to increase the leverage in high tax affiliates (like German ones) without unduly increasing the multinational's overall leverage. Unfortunately, we are not in a position to use the balance sheets of parent firms to find additional evidence for such countervailing effects abroad. But as pointed out in section 3 , the tax preferences for such a transaction should again be influenced by our variable DIFF and the tax attractiveness of third-party for financing German subsidiaries should be influenced by this variable. We therefore re-ran the regressions presented in table 2, but using thirdparty debt to balance sheet total as the endogenous variable (Table 3).

For the directly held affiliates (column (1)) DIFF has the expected sign and is significant, although the estimated coefficient is small. For indirectly held firms (column (2)) the coefficient turns out to be insignificant. If we instead use the variables

\footnotetext{
${ }^{11}$ Unfortunately, the Bundesbank data pool fixed assets and intangibles and fixed assets cannot be identified separately.

${ }^{12}$ For a discussion of similar financing strategies see Altshuler and Grubert (2003).
} 
CT and GERTAX, these results turn around: now the variable GERTAX has the expected and significant sign for indirectly held affiliates but is insignificant for directly held firms. The home country tax rate CT is insignificant in both cases. Together this provides only limited evidence that tax rates play a major role in the decision to raise outside debt.

PROFITABILITY again turns out to have a highly significant influence. The variable SIZE is positively correlated with third-party debt, which suggests that larger firms have better access to third party debt. COLLATERAL is significant and positively correlated with third-party debt in the case of directly held firms but is insignificant for indirectly held affiliates.

Table 3. Determinants of third-party debt

\begin{tabular}{ccccc}
\hline \hline & $\begin{array}{c}(1) \\
\text { Directly held } \\
\text { affiliates }\end{array}$ & $\begin{array}{c}(2) \\
\text { Indirectly held } \\
\text { affiliates }\end{array}$ & $\begin{array}{c}(3) \\
\text { Directly held } \\
\text { affiliates }\end{array}$ & $\begin{array}{c}(4) \\
\text { Indirectly held } \\
\text { affiliates }\end{array}$ \\
\hline DIFF & 0.034 & 0.013 & & \\
ACT & $(0.014)^{* *}$ & $(0.020)$ & -0.020 & 0.035 \\
& & & $(0.014)$ & $(0.025)$ \\
GERTAX & & 0.068 & 0.036 \\
PROFITABILITY & -0.222 & -0.120 & $(0.043)$ & $(0.018)^{* *}$ \\
& $(0.031)^{* * *}$ & $(0.030)^{* * *}$ & -0.222 & -0.146 \\
SIZE & 0.034 & 0.018 & $0.030)^{* * *}$ & $(0.033)^{* * *}$ \\
& $(0.009)^{* * *}$ & $(0.003)^{* * *}$ & $(0.009)^{* * *}$ & $(0.003)^{* * *}$ \\
COLLATERAL & 0.110 & -0.029 & 0.103 & -0.033 \\
& $(0.026)^{* * *}$ & $(0.021)$ & $(0.027)^{* * *}$ & $(0.020)$ \\
\hline Observations & 25,339 & 14,923 & 25,616 & 15,143 \\
Number of firms & 4,927 & 3,284 & 4,927 & 3,284 \\
R-squared & 0.80 & 0.57 & 0.80 & 0.57 \\
\hline \hline
\end{tabular}

Notes: Dependent variable: liabilities to affiliated companies outside Germany over the balance sheet total. Standard errors in parentheses; * significant at 10\%; ** significant at 5\%; *** significant at $1 \%$. Unbalanced sample for the years from 1996 to 2001. Firm fixed-effects (within) estimator. Standard errors are corrected for clustering across country observations and for heteroscedasticity. A full set of time dummies has been used; coefficient estimates are not reported. We eliminated outliers by excluding observations for which the exogenous variables PROFITABILITY, COLLATERAL and SIZE were either in their two lowest or in their two highest percentiles. We also excluded observations for which the endogenous variable was in the two highest percentiles. To be included observations had to be consecutive for at least three years. 


\section{Discussion}

The paper has analysed the financial structure of German inbound FDI in the nonfinancial sector. On average, some $25 \%$ of the balance sheet total of these firms was financed by intra-company loans in 2001 and for affiliates that are directly held by a foreign investor, cross-border intra-company loans account for $20 \%$ percent of balance sheet total. Tax rate differentials are frequently named as a possible explanation for this strong role of intra-company loans in financing foreign subsidiaries in Germany. If the interest on the loan is received in a low-tax country but is tax deductible in high-tax Germany, this financial instrument can produce a global tax saving for the multinational, the amount of which decreases in the foreign country's tax rate. Therefore we should expect that cross-border intra-company loans are used more extensively when the parent is located in a low-tax country. Based on a panel of 8,000 firms operating in Germany, we could provide only limited evidence that the home tax rate of the foreign parent is important for the amount of intra-company loans. Possibly, our analysis here suffers from lacking information on whether the foreign parent is in a loss position. In any case, the failure to identify sizeable effects of the home country tax rate does not imply that foreign affiliates that operate in Germany do not use financial strategies to save taxes. Our empirical results have shown that subsidiaries that on average are profitable do react more strongly to the German tax rate than other subsidiaries. This strongly suggests that the size of the German tax rate does play a role for the leverage decision. Considering third-party debt in the hand of Germany-based affiliates our results show a significant effect of the German tax rate when we look at indirectly held affiliates but not when we look at directly held affiliates.

Leverage decisions of foreign subsidiaries are certainly not exclusively steered by tax considerations, although these considerations do seem to play a role. Another important factor of cross-border intra-company loans is (low) profitability. The majority of cross-border intra-company loans are received by loss-making subsidiaries. In our panel analysis we find that for directly held foreign affiliates a reduction in profits by $1 \%$ of the balance sheet is associated with an increase of cross-border loans by $.3 \%$ of balance sheet total. Profitability, besides the different use of cross-border intra-company loans, is another area where directly and indirectly held firms differ starkly. Foreign- 
owned firms that are held via a German intermediate company show a much lower variation in profitability than do directly held affiliates and a majority of the indirectly held firms shows virtually zero profitability. Further analysis of these differences may potentially lead to additional insights into the tax avoidance strategies of multinational firms but are left for future research.

\section{References}

Alworth, J. (1988). The Finance, Investment and Taxation Decisions of Multinationals. Oxford: Basil.

Altshuler, R. and H. Grubert 2003. Taxes, Repatriation Strategies and Multinational Financial Policy. Journal of Public Economics, Vol. 87, 73-107.

Collins, J.H. and D.A. Shackelford 1998. Global Organizations and Taxes: An Analysis of the Dividend, Interest, Royalty, and Management Fee Payments between U.S. Multinationals' Foreign Affiliates. Journal of Accounting and Economics, Vol. 24, 151-173.

Desai, M.A., C. Fritz Foley, and J.R. Hines 2003a. A Multinational Perspective on Capital Structure Choice and Internal Capital Markets. Harvard NOM Research Paper No. 03-27.

Desai, M.A., C. Fritz Foley, and J.R. Hines 2003b. Chains of Ownership, Regional Tax Competition, and Foreign Direct Investment, in: H. Herrmann und R. Lipsey (eds.) Foreign Direct Investment in the Real and Financial Sector of Industrial Countries. Berlin: Springer, 61-98.

Deutsche Bundesbank (1993), "Trends in International Capital Links between Enterprises from the End of 1989 to the End of 1991", Monthly Report, April, 3348.

Deutsche Bundesbank (1997), "International Capital Links between Enterprises from the End of 1993 to the End of 1995", Monthly Report, May, 63-76.

Ederveen, S. and R. de Mooij 2001. Taxation and Foreign Direct Investment: a Metaanalysis. Quarterly Review of CPB Netherlands Bureau for Economic Policy Analysis.

Gentry, W. M. 1994. Taxes, Financial Decisions and Organizational Form: Evidence from Publicly Traded Partnerships, Journal of Public Economics, Vol. 53, 223244.

Givoly, D. C., A. Hain, R. Ofer, and O. Sarig 1992. Taxes and Capital Structure: Evidence from Firms' Response to the Tax Reform Act of 1986. Review of Financial Studies, Vol 5, 331-355.

Gordon, R.H. and Y. Lee 1999. Do Taxes Affect Corporate Debt Policy? Evidence from U.S. Corporate Tax Return Data, NBER Working Paper 7433.

Graham, J.R. 1999. Do Personal Taxes Affect Corporate Financing Decisions?, Journal of Public Economics, Vol. 73, 147-185. 
Gropp, R.E. 2002. Local Taxes and Capital Structure Choice. International Tax and Public Finance, Vol. 9, 51-71.

Grubert, H. and Mutti 1991. Taxes, Tariffs and Transfer Pricing in Multinational Corporate Decision Making. Review of Economics and Statistics, Vol. 73, 285293.

Harris, M. and A. Raviv 1991. The Theory of Capital Structure. The Journal of Finance, Vol.46, 297-355.

Jog, V. and J. Tang 2001. Tax Reforms, Debt Shifting and Tax Revenues: Multinational Corporations in Canada. International Tax and Public Finance, Vol. 8, 5-25.

Keen, M. 1991. Corporation Tax, Foreign Investment and the Single market, in: L.A. Winters and A.J. Venables (eds.) European Integration: Trade and Industry. Cambridge: Cambridge University Press, 165-199.

Lipponer, A. 2003. Deutsche Bundesbank's FDI Micro Database. Schmollers Jahrbuch - Zeitschrift für Wirtschafts- und Sozialwissenschaften, 123 (4), 593-600.

MacKie-Mason, J.K. 1990. Do Taxes Affect Corporate Financial Decisions? Journal of Finance, Vol. 45, 1471-1493.

Mintz, J. 2004. Conduit Entities: Implications of Indirect Tax-Efficient Financing Structures for Real Investment. International Tax and Public Finance, Vol. 11, 419-434.

OECD 1991. Taxing Profits in a Global Economy: Domestic and International Issues. Paris: OECD.

Rajan, R.G. and L. Zingales 1995. What Do We Know about Capital Structure ? Some Evidence from International Data. The Journal of Finance, Vol. 50, 1421-1460.

Rousslang, D.J. 1997. International Income Shifting by US Multinational Corporations. Applied economics, Vol. 29, 925-934.

Weichenrieder, A. 1995. Besteuerung und Direktinvestition. Tübingen: Mohr. 


\section{CESifo Working Paper Series}

(for full list see www.cesifo.de)

1289 Georg Götz and Klaus Gugler, Market Concentration and Product Variety under Spatial Competition: Evidence from Retail Gasoline, September 2004

1290 Jonathan Temple and Ludger Wößmann, Dualism and Cross-Country Growth Regressions, September 2004

1291 Ravi Kanbur, Jukka Pirttilä and Matti Tuomala, Non-Welfarist Optimal Taxation and Behavioral Public Economics, October 2004

1292 Maarten C. W. Janssen, José Luis Moraga-González and Matthijs R. Wildenbeest, Consumer Search and Oligopolistic Pricing: An Empirical Investigation, October 2004

1293 Kira Börner and Christa Hainz, The Political Economy of Corruption and the Role of Financial Institutions, October 2004

1294 Christoph A. Schaltegger and Lars P. Feld, Do Large Cabinets Favor Large Governments? Evidence from Swiss Sub-Federal Jurisdictions, October 2004

1295 Marc-Andreas Mündler, The Existence of Informationally Efficient Markets When Individuals Are Rational, October 2004

1296 Hendrik Jürges, Wolfram F. Richter and Kerstin Schneider, Teacher Quality and Incentives: Theoretical and Empirical Effects of Standards on Teacher Quality, October 2004

1297 David S. Evans and Michael Salinger, An Empirical Analysis of Bundling and Tying: Over-the-Counter Pain Relief and Cold Medicines, October 2004

1298 Gershon Ben-Shakhar, Gary Bornstein, Astrid Hopfensitz and Frans van Winden, Reciprocity and Emotions: Arousal, Self-Reports, and Expectations, October 2004

1299 B. Zorina Khan and Kenneth L. Sokoloff, Institutions and Technological Innovation During Early Economic Growth: Evidence from the Great Inventors of the United States, $1790-1930$, October 2004

1300 Piero Gottardi and Roberto Serrano, Market Power and Information Revelation in Dynamic Trading, October 2004

1301 Alan V. Deardorff, Who Makes the Rules of Globalization?, October 2004

1302 Sheilagh Ogilvie, The Use and Abuse of Trust: Social Capital and its Deployment by Early Modern Guilds, October 2004

1303 Mario Jametti and Thomas von Ungern-Sternberg, Disaster Insurance or a Disastrous Insurance - Natural Disaster Insurance in France, October 2004 
1304 Pieter A. Gautier and José Luis Moraga-González, Strategic Wage Setting and Coordination Frictions with Multiple Applications, October 2004

1305 Julia Darby, Anton Muscatelli and Graeme Roy, Fiscal Federalism, Fiscal Consolidations and Cuts in Central Government Grants: Evidence from an Event Study, October 2004

1306 Michael Waldman, Antitrust Perspectives for Durable-Goods Markets, October 2004

1307 Josef Honerkamp, Stefan Moog and Bernd Raffelhüschen, Earlier or Later: A General Equilibrium Analysis of Bringing Forward an Already Announced Tax Reform, October 2004

1308 M. Hashem Pesaran, A Pair-Wise Approach to Testing for Output and Growth Convergence, October 2004

1309 John Bishop and Ferran Mane, Educational Reform and Disadvantaged Students: Are They Better Off or Worse Off?, October 2004

1310 Alfredo Schclarek, Consumption and Keynesian Fiscal Policy, October 2004

1311 Wolfram F. Richter, Efficiency Effects of Tax Deductions for Work-Related Expenses, October 2004

1312 Franco Mariuzzo, Patrick Paul Walsh and Ciara Whelan, EU Merger Control in Differentiated Product Industries, October 2004

1313 Kurt Schmidheiny, Income Segregation and Local Progressive Taxation: Empirical Evidence from Switzerland, October 2004

1314 David S. Evans, Andrei Hagiu and Richard Schmalensee, A Survey of the Economic Role of Software Platforms in Computer-Based Industries, October 2004

1315 Frank Riedel and Elmar Wolfstetter, Immediate Demand Reduction in Simultaneous Ascending Bid Auctions, October 2004

1316 Patricia Crifo and Jean-Louis Rullière, Incentives and Anonymity Principle: Crowding Out Toward Users, October 2004

1317 Attila Ambrus and Rossella Argenziano, Network Markets and Consumers Coordination, October 2004

1318 Margarita Katsimi and Thomas Moutos, Monopoly, Inequality and Redistribution Via the Public Provision of Private Goods, October 2004

1319 Jens Josephson and Karl Wärneryd, Long-Run Selection and the Work Ethic, October 2004

1320 Jan K. Brueckner and Oleg Smirnov, Workings of the Melting Pot: Social Networks and the Evolution of Population Attributes, October 2004 
1321 Thomas Fuchs and Ludger Wößmann, Computers and Student Learning: Bivariate and Multivariate Evidence on the Availability and Use of Computers at Home and at School, November 2004

1322 Alberto Bisin, Piero Gottardi and Adriano A. Rampini, Managerial Hedging and Portfolio Monitoring, November 2004

1323 Cecilia García-Peñalosa and Jean-François Wen, Redistribution and Occupational Choice in a Schumpeterian Growth Model, November 2004

1324 William Martin and Robert Rowthorn, Will Stability Last?, November 2004

1325 Jianpei Li and Elmar Wolfstetter, Partnership Dissolution, Complementarity, and Investment Incentives, November 2004

1326 Hans Fehr, Sabine Jokisch and Laurence J. Kotlikoff, Fertility, Mortality, and the Developed World's Demographic Transition, November 2004

1327 Adam Elbourne and Jakob de Haan, Asymmetric Monetary Transmission in EMU: The Robustness of VAR Conclusions and Cecchetti's Legal Family Theory, November 2004

1328 Karel-Jan Alsem, Steven Brakman, Lex Hoogduin and Gerard Kuper, The Impact of Newspapers on Consumer Confidence: Does Spin Bias Exist?, November 2004

1329 Chiona Balfoussia and Mike Wickens, Macroeconomic Sources of Risk in the Term Structure, November 2004

1330 Ludger Wößmann, The Effect Heterogeneity of Central Exams: Evidence from TIMSS, TIMSS-Repeat and PISA, November 2004

1331 M. Hashem Pesaran, Estimation and Inference in Large Heterogeneous Panels with a Multifactor Error Structure, November 2004

1332 Maarten C. W. Janssen, José Luis Moraga-González and Matthijs R. Wildenbeest, A Note on Costly Sequential Search and Oligopoly Pricing, November 2004

1333 Martin Peitz and Patrick Waelbroeck, An Economist's Guide to Digital Music, November 2004

1334 Biswa N. Bhattacharyay and Prabir De, Promotion of Trade, Investment and Infrastructure Development between China and India: The Case of Southwest China and East and Northeast India, November 2004

1335 Lutz Hendricks, Why Does Educational Attainment Differ Across U.S. States?, November 2004

1336 Jay Pil Choi, Antitrust Analysis of Tying Arrangements, November 2004

1337 Rafael Lalive, Jan C. van Ours and Josef Zweimueller, How Changes in Financial Incentives Affect the Duration of Unemployment, November 2004 
1338 Robert Woods, Fiscal Stabilisation and EMU, November 2004

1339 Rainald Borck and Matthias Wrede, Political Economy of Commuting Subsidies, November 2004

1340 Marcel Gérard, Combining Dutch Presumptive Capital Income Tax and US Qualified Intermediaries to Set Forth a New System of International Savings Taxation, November 2004

1341 Bruno S. Frey, Simon Luechinger and Alois Stutzer, Calculating Tragedy: Assessing the Costs of Terrorism, November 2004

1342 Johannes Becker and Clemens Fuest, A Backward Looking Measure of the Effective Marginal Tax Burden on Investment, November 2004

1343 Heikki Kauppi, Erkki Koskela and Rune Stenbacka, Equilibrium Unemployment and Capital Intensity Under Product and Labor Market Imperfections, November 2004

1344 Helge Berger and Till Müller, How Should Large and Small Countries Be Represented in a Currency Union?, November 2004

1345 Bruno Jullien, Two-Sided Markets and Electronic Intermediaries, November 2004

1346 Wolfgang Eggert and Martin Kolmar, Contests with Size Effects, December 2004

1347 Stefan Napel and Mika Widgrén, The Inter-Institutional Distribution of Power in EU Codecision, December 2004

1348 Yin-Wong Cheung and Ulf G. Erlandsson, Exchange Rates and Markov Switching Dynamics, December 2004

1349 Hartmut Egger and Peter Egger, Outsourcing and Trade in a Spatial World, December 2004

1350 Paul Belleflamme and Pierre M. Picard, Piracy and Competition, December 2004

1351 Jon Strand, Public-Good Valuation and Intrafamily Allocation, December 2004

1352 Michael Berlemann, Marcus Dittrich and Gunther Markwardt, The Value of NonBinding Announcements in Public Goods Experiments: Some Theory and Experimental Evidence, December 2004

1353 Camille Cornand and Frank Heinemann, Optimal Degree of Public Information Dissemination, December 2004

1354 Matteo Governatori and Sylvester Eijffinger, Fiscal and Monetary Interaction: The Role of Asymmetries of the Stability and Growth Pact in EMU, December 2004

1355 Fred Ramb and Alfons J. Weichenrieder, Taxes and the Financial Structure of German Inward FDI, December 2004 